\title{
CURRENT SECURITY SITUATION IN THE SOUTH CAUCASUS: WIDER REGIONAL CONTEXT
}

\author{
Armen Grigoryan \\ Central European University \\ Budapest, Hungary \\ grigoryanarmen@yahoo.com
}

\begin{abstract}
While unsolved conflicts in the South Caucasus are sometimes labelled "frozen", that is basically a misnomer: there is a volatile situation with a potential for large-scale violence. In addition to the persistent threat for human security, the situation in that part of the EU's periphery may potentially threat oil and gas supply routes and other transportation corridors, particularly between Europe and Central Asia. Furthermore, the situation is additionally complicated by multiple antagonisms between global and regional powers. This article offers a review of the situation taking into consideration the mentioned issues and examining the current security situation in the South Caucasus within a wider regional context. The article also examines Russia's regional interests and the attitudes of other regional actors - Iran and Turkey, and their relations with the South Caucasian countries.
\end{abstract}

\section{Keywords}

Conflicts, energy, regional security, South Caucasus, transportation 


\section{THE SITUATION CONCERNING THE NAGORNO- KARABAKH CONFLICT}

Two so-called "four-day war" - the fighting between the Armenian forces in Nagorno-Karabakh and Azerbaijani army units between 2 April and 5 April 2016 - has been the largest incident on the line of contact since the cease-fire reached in 1994. Both sides used heavy weapons such as tanks and artillery. For the first time since the cease-fire, Azerbaijan used helicopters and multiple rocket launchers, as well as unmanned aerial vehicles (UAV).

The "four-day war" followed the pattern of the recent years' cease-fire violations, with a gradual increase in the power of used weapons. For several years, sniper fire was exchanged occasionally, despite international mediators' repeated calls to withdraw the snipers from the line of contact. Later on, machine-guns were used, and then, in 2015, artillery. Already then regional and foreign experts warned that the risk of a "war by accident" was increasing. Characteristically, Armenian and Azerbaijani experts, as well as several Western observers, were sceptical concerning the possibility to advance conflict resolution while Russia's regional influence remained strong, particularly considering that Russia was not only one of the mediators but also the main arms supplier to both sides, and, in the words of the director of the Yerevan-based Regional Security Centre, Richard Giragosian, "the main determinant of either deterrence or disaster" (Grigoryan 2015b).

Quite significantly, with the exception of Israeli-made UAVs, all other heavy weapons used by Azerbaijan during the "four-day war", including the helicopters and TOS-1A thermobaric multiple rocket launchers, had been supplied by Russia in the recent few years. Russian sources admitted that although Armenia had been able to buy weapons at discounted prices as a member of the Russia-led Collective Security Treaty Organisation (CSTO), parity was not the case since Azerbaijan's military spending had been about 20 times larger (Nikolsky and Ilyina 2016). Characteristically, immediately after the "fourday war" Russian Prime Minister Dmitry Medvedev said that Russia would continue supplying weapons to both Armenia and Azerbaijan, as weapons 
"should only be used for deterrence", while supplies from other countries would result in a disbalance (RIA Novosti 2016).

Considering Russia's ambiguous role, known Azerbaijani expert Zaur Shiriyev, academy fellow with the Russia and Eurasia Programme at Chatham House, noted:

\begin{abstract}
"Azerbaijan's military offensive and its policies during the period of escalation may have been precipitated by a "gentlemen's agreement" between Baku and Moscow; or Russia could have given Azerbaijan a kind of "green light" for military action, as long as the latter refrained from pushing Armenia to question its strategic alliance with Moscow. Whether or not such an understanding was reached, clearly Baku did not cross Moscow's red line-i.e. April's military operation did not lead to a full-fledged war. At the same time, Russia benefits financially from this situation and so is taking a business-like approach. The Azerbaijani army's military offensive means that Baku will need to negotiate the purchase of replacement military equipment from Moscow in the future. At the same time, Yerevan is also requesting help to arm its military. This situation strengthens Russia's role in conflict management" (Shiriyev 2016).
\end{abstract}

Observers from the Warsaw-based Centre for Eastern Studies also noted: "it is possible that Azerbaijan did not act alone, and that Russia may have at least been aware of Baku's intentions". Thus, Russia might have tried to strengthen its dominance in the region by imposing a resolution that only it could guarantee (primarily involving the introduction of Russian peacekeeping forces in the conflict zone). Therefore, they argued,

"Moscow's attitude in the current conflict, which has at the very least been ambiguous, is revealed by facts like these: [...] the stoking of tensions by the Russian media (including Sputnik Armenia and Azerbaijan, Lifenews.ru, etc.); the unexpected publication by Russian (and not Armenian or Azerbaijani) sources of reports of a ceasefire; and the emphasis on the bilateral nature of the ceasefire (i.e. between Azerbaijan and the so-called Republic of Nagorno-Karabakh). In addition, as Armenia's defence minister announced on 6 April, the ceasefire was reached during a meeting between the chiefs of staff of Azerbaijan and Armenia which took place in Moscow" (Jarosiewicz and Falkowski 2016). 
At the South Caucasus Security Forum in April 2017 Giragosian argued that the "four-day war" had been a success for Azerbaijan, which had been capable to seize some tactically significant territory after years of frustration, while there had been a limited response by Armenia, which had had a lack of deterrence. Furthermore, he argued that while the hawks in Moscow could push for a possible deployment of Russian peacekeepers in Nagorno-Karabakh, all involved parties would not want that, as in that case "Russia is the only winner in Nagorno-Karabakh". He also expressed concern that next confrontation would likely be more serious, involving heavier weapons (Strategic Policy Institute 2017, 10-2). It has also been noted that if resumed, the conflict "carries significant risks of spreading, since it divides the three regional powers (Iran, Russia and Turkey)" (MacFarlane 2018, 143).

After the "four-day war", Armenia amended its military doctrine, stepping back from an obsolete Soviet-style "Static Defence" doctrine and adding a deterrence component opening the door to a pre-emptive strike in case an assault by the adversary is "imminent". At the same time, the rhetoric about using ballistic missiles to target Azerbaijan's hydrocarbon infrastructure is supposedly just a political tool of containment, and it is unlikely that the Armenian side would risk damaging the Azerbaijani portion of an energy network that is of increasing importance for Europe's energy security (Abrahamyan 2017).

Though sometimes labelled "frozen", the Nagorno-Karabakh conflict has cost hundreds of lives in the recent few years. It remains the most dangerous conflict in the Caucasus region. According to the Stockholm International Peace Research Institute, military expenditures continued growing in 2017, reaching 437 million US dollars in Armenia and 1.48 billion US dollars in Azerbaijan (SIPRI Military Expenditure Database 2018). This tendency will probably remain as mediation efforts by the OSCE Minsk Group co-chairs - France, Russia and the United States - are unlikely to bring about quick progress towards a negotiated resolution.

In addition to the rigid posture of the conflicting parties, the geopolitical component plays a significant role. On the one side, France and the United States lack the capacity to influence and persuade the conflicting sides. On the other side, although currently Russia is not interested in conflict escalation, perhaps 
because the OSCE Minsk Group is one of the few frameworks where there is a possibility of cooperation rather than confrontation with the West, Moscow is still not likely to act in favour of a final resolution unless it gets an opportunity to deploy its "peacekeeping" troops in order to have a stronger influence on both Armenia and Azerbaijan.

The negotiations were practically suspended few months ago, as the ruling regimes of both Armenia and Azerbaijan were preparing to reproduce themselves. While the presidential elections in Azerbaijan on 11 April 2018 predictably resulted in re-election of the incumbent president, Ilham Aliyev, in Armenia rather unexpected developments took place. The former president, Serzh Sargsyan, attempted to continue ruling as a prime minister after the end of his second presidential term. For that purpose, the constitution had been amended in 2015, transferring executive power from the president to the prime minister. However, a two-week civil disobedience campaign forced Sargsyan to resign (Grigoryan 2018). Protest leader Nikol Pashinyan, elected the new prime minister on 8 May, announced a shift in the policy vis-à-vis conflict resolution, making three points contrasting Sargsyan's former policy. First, he supported the current negotiations framework, yet stressed that as Armenia's prime minister he would solely represent Armenia, as only Nagorno-Karabakh leadership could speak on behalf of the non-recognised republic. ${ }^{1}$ Second, Pashinyan declared that "unless Azerbaijan reverses its militaristic rhetoric, threatening to annex Yerevan, Sevan, Zangezur and Stepanakert" any dialogue with Baku on a potential consensus would be pointless. Third, he stated that "mutual concessions can be negotiated only if Azerbaijan gives a clear message that Baku is ready to recognize the right of the people of Artsakh2 to self-determination" (Abrahamyan 2018). The basic principles for the settlement of the NagornoKarabakh conflict within the OSCE Minsk Group framework are based on the

1 Originally, there was a trilateral format including the de facto authorities of NagornoKarabakh. Since 1998, only representatives of Armenia and Azerbaijan have been participating in the negotiations.

2 Artsakh is the historical Armenian name of Karabakh, unilaterally adopted as the official name of state in 2017. 
Helsinki Final Act (1975) principles of non-use of force, territorial integrity, and the equal rights and self-determination of peoples.

\section{THE SITUATION IN ABKHAZIA AND SOUTH OSSETIA AND RUSSO-GEORGIAN RELATIONS}

In near 10 years since the Russo-Georgian war and Russia's unilateral recognition of independence of the two breakaway territories, the situation, although less dramatic than on the line of contact in Nagorno-Karabakh, is also not quite "frozen". While full integration of Abkhazia and South Ossetia into Russia does not seem to be on the agenda, military cooperation with them has been increasing; since 2017, residents of South Ossetia may also be recruited into the Russian army (Duncan 2018, 249). The ongoing "borderisation", i.e., erecting borders between Russian-occupied territories and Georgia proper, remains a major source of tension. Russian border guards have been marking the administrative border of South Ossetia as a "state border", gradually moving south and dividing Georgian settlements with barbed wire, so residents are denied access to their arable land or other property, and often get arrested.

In July 2015, the Georgian authorities reported that as Russian border guards moved south by 300 metres, a 1.6 kilometre segment of the BP-operated BakuSupsa pipeline remained under Russia's effective control, and only a 500 metres distance was left between the barbed wire and the main Georgian highway linking country's eastern and western parts (Bugajski and Assenova 2016, 336). Georgian Prime Minister, Giorgi Kvirikashvili, said in an interview in 2016 that there was no improvement, as "Russia never appreciates when you concede or make a step forward or compromise. They always take it for granted". He also insisted that his government had no intention to confront Russia militarily, yet the new borders would not last (Higgins 2016). The "borderisation" went on later as well, getting more villages divided (Agenda 2017). As recent as March 2018, tensions grew as a Georgian citizen, Archil Tatunashvili, died while he was in custody in South Ossetia, and the body was released to his family for a burial 
only a month later. Following a medical examination, Georgia's Ministry of Interior concluded that Tatunashvili had been tortured and murdered (Rukhadze 2018).

Yet, in April the government of Georgia made public a new initiative called "A Step toward a Better Future". The plan is meant to encourage contacts, movement and relations between Georgia and the residents of Abkhazia and South Ossetia who would be able to transport locally produced goods to Georgia-controlled territories with status-neutral labelling and get funding for small business projects. Goods produced in Abkhazia and South Ossetia would also be approved for sales on the European Union market with Georgian certificates of origin. Furthermore, residents of Abkhazia and South Ossetia would be able to use banking, vehicle registration and other services, as well as attend Georgian educational institutions, without obtaining Georgian citizenship. However, the de facto authorities of both Abkhazia and South Ossetia refused the proposal (Menabde 2018b). At the same time, the government's proposal received strong domestic criticism: critics considered that it risked undermining the international status quo on non-recognition of the separatist regions (Rukhadze 2018).

In addition to the "borderisation", Russia has also been using different subversive methods. Russian official circles have managed to establish connections with some political parties in Georgia, particularly those promoting anti-Western sentiments. A number of non-governmental organisations not making their funding sources public have been established, including such umbrella organisations as the Eurasian Institute, which mainly focuses on analytical activities and organises conferences and workshops, and the Eurasian Choice, which, being a partner of the International Eurasian Movement led by Russia's Eurasianist ideologist, Alexander Dugin, mainly organises demonstrations and social activities (Grigoryan 2017, 145-6). According to a recent report on the risks to the country's security published by the State Security Service of Georgia, a "foreign state" has been organising an agent network inside Georgia with the purpose of influencing the decisions of the parliament, the government and other state institutions, provoking anti-Western attitudes, polarisation, destabilisation, and conflicts on ethnic and religious grounds. 
Furthermore, foreign special services "are trying to disguise their activities as commercial, diplomatic, religious and humanitarian projects" (Menabde 2018a). Furthermore, the joint Russo-Armenian air defence, Russia's growing military presence on the occupied Georgian territories, as well as the militarisation in the Black Sea area in general, present additional threats. As noted by senior fellow of the Georgian Foundation for Strategic and International Studies, Shota Utiashvili, with air defence units covering almost entire Georgian airspace, Russia is using the Anti-Access/Area Denial (2A/AD) strategy, and its main goal is to deter Georgia's NATO membership (Strategic Policy Institute 2017, 10).

\section{IRAN'S RELATIONS WITH ARMENIA AND AZERBAIJAN}

As noted previously, Iran's relations with Armenia and Azerbaijan, as well as Iran's approach towards the Nagorno-Karabakh conflict, refute the perception of some outside observers that the conflict had somehow been related to the religious difference between Christian Armenians and Shiite Muslim Azerbaijanis (Grigoryan 2016b, 226). MacFarlane notes that the South Caucasus is a useful place to test the proposition that regional security challenges in the region might be explained in terms of civilisational rivalry: the consistent propensity of the regional states to align across civilisational lines (AzerbaijanGeorgia-Turkey, Armenia-Iran, etc.) suggests that is not a promising line of enquiry (MacFarlane 2018, 146). Since the 1990s, Iran's relations with Armenia reinforced Tehran's role of a regional actor in the South Caucasus.

On the other side, Azerbaijan, despite having a shared culture, was largely perceived as a threat towards Iran's national security because of the large ethnic Azerbaijani population in the north-western part of Iran, and in turn, Azerbaijan perceived Iran's attitude vis-à-vis the Nagorno-Karabakh conflict as proArmenian; that resulted in some anti-Iranian sentiments in Azerbaijan (Gafarl,, Anapiosyan, Chapichadze and Öztarsu 2016, 55). Iran has also been concerned by Azerbaijan's cooperation with Israel, including weapon supplies and, allegedly, allowing Israel to run intelligence operations from Azerbaijan's territory, while Azerbaijan used to accuse Iran of attempts to promote its 
fundamentalist approach to Islam. Besides, there were disputes between the two countries concerning Iranian military presence in the Caspian Sea and ownership of some offshore oilfields (Grigoryan 2016b, 227). Geybulla notes that Iran's relations with Azerbaijan improved with the election of President Hassan Rouhani in 2013. Yet, Iran, with its estimated gas reserves 30 times greater than Azerbaijan's and large proven oil reserves, remains a serious challenge for Baku as a potential regional energy player: "The possibility of Iran joining Europe's energy diversification plans and playing a key role in keeping oil prices low is a further source of grievance to Azerbaijan" (Geybulla 2018, 107).

Armenia's relations with Iran have been negatively influenced by Yerevan's tendency to yield to Russian pressure and limit participation in international projects whenever those would contradict Russia's interests. Back in 2005, the Armenian government rejected a proposal to build a pipeline for transit of natural gas from Iran to Europe via Georgia and Ukraine. Prime Minister Andranik Margaryan bluntly declared that the government could not neglect Russia's interests. So, instead of the initially planned 1400 millimetres, the diameter of the Iran-Armenia pipeline was reduced to 700 millimetres, reducing the capacity fourfold. Moreover, as the construction was completed in 2007, Armenia disappointed the Iranian partners by selling its share to Russia. Now only about 35 percent of the pipeline's capacity is used: limited quantities of gas are supplied by Iran in exchange for electricity produced by Armenia's thermal power plants. Gas for internal consumption in Armenia is supplied by Russia's Gazprom, and while Iranian officials made several suggestions that Iran could offer cheaper gas than Russia, their Armenian counterparts turned a deaf ear (Grigoryan 2016b, 226).

After the Iran nuclear deal, Tehran kept proposing to finance the construction of a new pipeline. According to Iranian news agencies' reports, President Rouhani told his Armenian counterpart Serzh Sargsyan in 2016: "we need to spare no effort in connecting the Persian Gulf to the Black Sea". Yet, even despite an offer to fully finance the pipeline construction no progress could be achieved. At the same time, the Armenian government proposed building a railway yet was not capable to attract investors while the estimated cost of construction exceeded 3 billion US dollars (Grigoryan 2016a). 
In December 2017 Armenia opened a free economic zone in Meghri, a city near the Iranian border, aiming to become a broker between Iran and the Eurasian Economic Union (EEU). The EEU and Iran signed a free trade agreement abolishing customs duties for Iran's trade with EEU members on 17 May 2018 for a three-year term, and there were some hopes that it might boost mutual trade (Jardine 2018b).

However, although there is potentially a possibility to reduce consumer prices of Iranian goods sold in Armenia, the idea of becoming a "bridge between Iran and the EEU", which has been recurrent in the Armenian political discourse for several years, is hardly realisable. The absence of convenient means of transportation makes the prospects of growth in that field rather dubious. There is no railway link between Armenia and Iran, and the Abkhazian segment of the Georgian railway cannot be used, so there is no connection to Russia. In turn, the automobile road connecting Armenia to Russia cannot be used in the winter as its section between Georgia and Russia becomes impassable because of the weather conditions. Although Georgia and Russia in 2017 signed an agreement to open "trade corridors" - roads connecting the two countries via Abkhazia and South Ossetia, there is little prospect for its implementation. As noted by Kornely Kakachia, director of the Georgian Institute of Politics, "it won't help Armenia's plans for a transit corridor without major concessions from Moscow on the status of the breakaway regions" (Jardine 2018a). Any such concession seems hardly possible in a short-term perspective.

Meanwhile, in January 2018 Azerbaijan and Iran agreed to build a 205-kilometer railway from Rasht to the Azerbaijani border, and the network may be fully ready by summer. Besides, transportation between Iran and EEU members Kazakhstan and Russia is also possible by the Caspian Sea. So, while Armenia may have lost some more feasible opportunities, the potential for transit between Iran and Russia via Armenia is insignificant.

Furthermore, Azerbaijan and Iran have made a decisive step towards resolution of a prolonged dispute concerning ownership of some offshore oilfields in the Caspian Sea. As part of that dispute, back in 2001 Iranian gunboats and aircraft threatened Azerbaijani ships surveying some of the contested areas; as a result, BP suspended some of its operations. On 28 March 2018, during President 
Rouhani's official visit to Baku, a memorandum of understanding on joint development of offshore hydrocarbon fields in the Caspian Sea was signed (Rahimov 2018). Shortly before that, Baku hosted the first official ministerial meeting of a new regional format, encompassing Azerbaijan, Georgia, Iran and Turkey, aiming to enhance cooperation among the four neighbouring states, particularly in the security sphere. The new regional format is to amend the trilateral political and economic cooperation between Azerbaijan, Georgia and Turkey (Shahbazov 2018).

\section{TURKEY'S ROLE IN THE SOUTH CAUCASUS}

Turkey has been Georgia's largest trade partner and a major investor, and one of Azerbaijan's principal trade partners. The three countries closely cooperate in the security, trade, transportation and energy spheres. In addition to the already functioning pipelines, the Trans-Anatolian Natural Gas Pipeline (TANAP) started operation on 12 June. Its annual capacity is 16 billion cubic meters (bcm), from which Turkey will use $6 \mathrm{bcm}$, reducing the share of Russian gas accordingly, and $10 \mathrm{bcm}$ will be delivered to Europe. It is planned to use additional investments to increase the capacity to $31 \mathrm{bcm}$ per annum (Daily Sabah 2018). The railway corridor between the three countries has gradually been increasing its share in international trade, allowing cargo deliveries between Europe and China, with railway wagons being transported by ferries between Azerbaijan and Kazakhstan.

Despite the absence of diplomatic relations and closed border, Turkey's share in Armenia's foreign trade has been growing with the use of the Georgian transit route. Turkey was Armenia's eighth largest trade partner in 2015 and sixth largest in 2016, the top five being Russia, the EU, China, Georgia and Iran (Statistical Yearbook of Armenia 2017, 477-9). 


\subsection{The current stage of Armenian-Turkish relations}

The process of ratification of the Armenian-Turkish protocols signed in October 2009 was suspended by Armenia's President Serzh Sargsyan in 2015, and the protocols were declared null and void on 1 March 2018, few weeks before the end of Sargsyan's presidential term. As a matter of fact, the ratification had already been postponed indefinitely years before the formal suspension, as Turkey's then Prime Minister Recep Tayyip Erdoğan declared that opening of the border and establishing diplomatic relations with Armenia would depend on Armenia's agreement with Azerbaijan over Nagorno-Karabakh. Such a change of approach was the result of Azerbaijan's harsh reaction to the Armenian-Turkish protocols and the so-called "football diplomacy" which had preceded them.

Perhaps paradoxically, Russian intelligence was Azerbaijan's source of detailed information about the substance of negotiations between Ankara and Yerevan. Particularly, it informed Baku that progress on Nagorno-Karabakh had not been included in the draft protocols as a precondition for rapprochement (Shiriyev and Davies 2013, 190). As a result, Azerbaijan made a strong effort to mobilise support among Turkish politicians and media, and then signed an agreement with Russia's Gazprom to sell 500 million cubic meters of gas yearly, starting in 2010. Thus, Azerbaijan used active lobbying and its "trump card" - the gas supply issue - to make clear: "either Turkey ensured that Baku's demands were met in its negotiations with Armenia, or else Azerbaijan would continue to court Russia and send its Caspian energy supplies elsewhere. The threat and indeed concrete action suggested significant political and economic sanctions in punishment for Turkey's policy shift" (Shiriyev and Davies 2013, 193-4).

Soon after the suspension of the protocols by Sargsyan in 2015, Suat Kınıklioğlu, who at the time of signing of the protocols had been a member of the executive board of Erdoğan's Justice and Development Party (AKP) and the spokesman of the foreign affairs committee in the Turkish parliament, reconfirmed that Russia had disclosed the protocols to Azerbaijan and argued that a normalisation of relations had been made impossible by linking it to the Nagorno-Karabakh issue. Kınıklığlu challenged the assertions of some Turkish and Western analysts that the closed border could persuade Armenia to make concessions while opening 
the border would decrease Yerevan's motivation in the peace process. He considered that if the border had been opened, "the South Caucasus would have been a much safer region" (Grigoryan 2015a).

Russia's eagerness to provide critical information about the confidential Armenian-Turkish negotiations to Azerbaijan does not seem that paradoxical as the outcomes are considered. The failure to normalise the Armenian-Turkish relations helped to advance Russia's goals. Already in 2010 Russia persuaded Armenia to extend the deployment of its 102nd military base in Gyumri until 2044. Then, in 2013, Russia's security guarantees vis-à-vis Azerbaijan and Turkey became an excuse for persuading Armenia to abandon the Association Agreement with the European Union and to join the Customs Union (the predecessor of the Eurasian Economic Union). Simultaneously, since 2010, Russia started selling offensive weapons worth billions of dollars to Azerbaijan, thereby further reducing Armenia's possibilities for manoeuvre (Grigoryan 2015a).

Armenia and Turkey may supposedly again seek a normalisation of the bilateral relations, although a new round of negotiations would be required. Following the recent government change in Armenia, new Prime Minister Nikol Pashinyan told about readiness to establish diplomatic relations with Turkey: "Turkey is putting forward preconditions. This demand is illogical because it is illogical to put forward conditions related to a third country in order to establish relations with any country. We do not change our position and we are ready to establish relations without conditions. At the same time, we remain committed to international recognition of the Armenian genocide". In response, Turkish Prime Minister Binali Yıldırım said: "If Armenia gives up its hostile attitude, which it has shown for years against Turkey, if gives up its wrong attitude against Turkey's territorial integrity and borders, if wants to opens [sic] a new page then we will respond accordingly after looking at the details" (Hürriyet Daily News 2018). It still seems hardly possible to achieve a normalisation without a substantial breakthrough in the Nagorno-Karabakh conflict resolution process. 


\section{CONCLUSIONS}

In a short-term perspective, the situation in the South Caucasus will likely remain unstable. In addition to the mentioned conflicts, many other factors influence the situation in the region and its neighbourhood: Iranian and Russian military engagement in Syria, with possibilities of collision with Israeli or Western forces; the U.S. withdrawal from the Iran nuclear deal and Tehran's possible reaction, as well as the dispute between the U.S. and the EU concerning the issue; the U.S. sanctions against Russia, which may at some point affect Armenia's or Azerbaijan's political and military cooperation with Moscow; possibility of further escalation in the east of Ukraine and other possible reasons for further deterioration of Russia's relations with the West; several aspects of Russo-Turkish relations; and so forth.

The EU lacks influence on the conflicting parties and therefore has limited opportunities to advance conflict resolution more directly. However, it has a vital interest in regional stability and has some tools that may be further developed. It is possible to strengthen the Comprehensive Institution Building programme and increase support, particularly within the Eastern Partnership framework, for countries achieving demonstrable governance reforms and progress regarding human rights and respect for the rule of law, thereby contributing to stabilisation and dialogue. Offering programmes of cooperation tailored to the needs and choices of each partner in the neighbourhood and involving the partners in the designing of projects of cooperation as owners of the process seems a feasible policy.

At the same time, while it is explicable that pragmatic interests will sometimes prevail over values, partner states' political elites should not be rewarded for their costly and often destabilising pursuit of self-interest. It has been noted: "The European norms are often taken over formally while in reality all the substantial reforms remain imitated by the pseudo-European elites. In this process, a part of the responsibility is certainly borne by the European institutions that are responsible for monitoring the progress made by such countries but often, due to the geopolitical stakes, the 'sins' are forgiven in exchange for displaying a pro-European attitude. This situation undoubtedly 
corrupts the entire image of the EU and of its normative values" (Scrinic 2014, 228). Such a situation could particularly be observed in the case of EU-Armenia relations during the previous government's tenure in Yerevan, and it disappointed many of the citizens who noticed some approaches based on double standards.

To sum up, there is a potential for achieving a better balance between values and pragmatism, thereby strengthening the EU as an international actor capable to better deal with challenges in the neighbourhood and beyond. Contributing to peace, stability, democracy, good governance and strengthening of the rule of law in the South Caucasus countries is a win-win programme of action, and while it may require some additional financial investment in a short term, longer-term benefits would be worth it. A stable and secure South Caucasus would contribute more to the EU's energy security and international trade, increasing the demand for EU-based companies' goods and services. Sustainable stability and improved governance could also help to attract more investments and advance economic development in the region, reducing the need for direct financial assistance in a longer term.

\section{REFERENCES}

- $\quad$ Abrahamyan, Eduard. 2017. “Armenia Amends New Military Doctrine in Standoff with Azerbaijan over Karabakh". Eurasia Daily Monitor, Vol. 14 issue 127, October 11, 2017. https://jamestown.org/program/armenia-adopts-newmilitary-doctrine-standoff-azerbaijan-karabakh/.

- Abrahamyan, Eduard. 2018. "Pashinyan Stiffens Armenia's Posture toward Karabakh". Eurasia Daily Monitor, Vol. 15 issue 72, May 10, 2018. https://jamestown.org/program/pashinyan-stiffens-armenias-posture-towardkarabakh/.

- $\quad$ Agenda. 2017. "Creeping Occupation: Russia Advances 10 Hectares into Georgian Territory". Accessed May 14, 2018. http://agenda.ge/news/82746/eng. 
- Bugajski, Janusz, and Margarita Assenova. 2016. Eurasian Disunion: Russia's Vulnerable Flanks. Washington, D.C.: The Jamestown Foundation.

- Daily Sabah. 2018. "Poised to Boost Europe's Supply Security, TANAP to Start First Gas Delivery June 12". Daily Sabah, May 11, 2018. https:/ / www.dailysabah.com/energy/2018/05/11/poised-to-boost-europessupply-security-tanap-to-start-first-gas-delivery-june-12.

- $\quad$ Duncan, Peter J. S. 2018. "Russia and the South Caucasus". In The South Caucasus - Security, Energy and Europeanization, edited by Meliha B. Altunisik and Oktay F. Tanrisever, 235-52. London and New York: Routledge.

- Gafarlı, Orhan, Arevik Anapiosyan, Khatuna Chapichadze and Mehmet Fatih Öztarsu. 2016. "The Role of Global and Regional Actors in the South Caucasus". Caucasus Edition - Journal of Conflict Transformation July 2016: 35-70.

- Geybulla, Arzu. 2018. “The Third Powers and Azerbaijan”. In Chaillot Paper 144: Third Powers in Europe's East, edited by Nicu Popescu and Stanislav Secrieru, 101-10. Paris: European Union Institute for Security Studies.

- Grigoryan, Armen. 2015a. “Turkey-Armenia Relations after Turkey's Elections". Central Asia - Caucasus Analyst, Vol. 17 issue 11, June 10, 2015. http:/ / www.cacianalyst.org/publications/analytical-articles/item/13225turkey-armenia-relations-after-turkey's-elections.html.

- Grigoryan, Armen. 2015b. "Moscow Frustrates Attempts to Resolve Karabakh Conflict, and Curtails Yerevan's Foreign Policy Options". Eurasia Daily Monitor, Vol. 12 issue 200, November 4, 2015. https:/ /jamestown.org/program/moscow-frustrates-attempts-to-resolvekarabakh-conflict-and-curtails-yerevans-foreign-policy-options/.

- Grigoryan, Armen. 2016a. "Russian Factor Remains Critical for Armenia's Regional Projects". Eurasia Daily Monitor, Vol. 13 issue 41, March 1, 2016. https://jamestown.org/program/russian-factor-remains-critical-forarmenias-regional-projects/.

- Grigoryan, Armen. 2016b. "The Nagorno-Karabakh Conflict and Regional Security: The Implicit Interests of Regional Players". In Panorama of Global Security Environment 2015-2016, edited by Peter Bátor and Róbert Ondrejcsák, 221-9. Bratislava: Strategic Policy Institute. 
- Grigoryan, Armen. 2017. "Russia's Intervention in the Post-Soviet Countries: Eurasianist Ideology as a Justification". In Russia and the Former Soviet Space: Instrumentalizing Security, Legitimizing Intervention, edited by Vasile Rotaru and Miruna Troncotă, 124-53. Newcastle upon Tyne: Cambridge Scholars Publishing.

- Grigoryan, Armen. 2018. “Armenia's Prime Minister Resigns amid Extensive Protests". Central Asia - Caucasus Analyst, May 2, 2018. http:/ / cacianalyst.org/publications/analytical-articles/item/13511-armeniasprime-minister-resigns-amid-extensive-protests.html.

- $\quad$ Higgins, Andrew. 2016. “In Russia's 'Frozen Zone,' a Creeping Border with Georgia". The New York Times, October 23, 2016. https://www.nytimes.com/2016/10/24/world/europe/in-russias-frozen-zonea-creeping-border-with-georgia.html.

- $\quad$ Hürriyet Daily News. 2018. "Turkey Will Respond Positively 'If Armenia Abandons Hostile Attitude,' Says Y1ldırım". Hürriyet Daily News, May 11, 2018. http:/ / www.hurriyetdailynews.com/turkey-will-respond-positively-if-armeniaabandons-hostile-attitude-says-yildirim-131698.

- Jardine, Bradley. 2018a. "Armenia and Azerbaijan Compete to Attract Iranian Cargo". EurasiaNet, April 9, 2018. https://eurasianet.org/s/armeniaand-azerbaijan-compete-to-attract-iranian-cargo.

- Jardine, Bradley. 2018b. “Armenia Hopes to Benefit from New IranEurasian Union Free Trade Deal". EurasiaNet, May 18, 2018. https:/ / eurasianet.org/s/armenia-hopes-to-benefit-from-new-iran-eurasianunion-free-trade-deal.

- Jarosiewicz, Alexandra, and Maciej Falkowski. 2016. "The Four-Day War in Nagorno-Karabakh". https://www.osw.waw.pl/en/publikacje/analyses/2016-04-06/four-day-warnagorno-karabakh.

- MacFarlane, S. Neil. 2018. "Regional Powers and Security in the Caucasus". In The South Caucasus - Security, Energy and Europeanization, edited by Meliha B. Altunisik and Oktay F. Tanrisever, 143-61. London and New York: Routledge. 
- $\quad$ Menabde, Giorgi. 2018a. "Georgian Special Services Publicize Russia's Attempts to Subvert Country from Within". Eurasia Daily Monitor, Vol. 15 issue 55, April 11, 2018. https://jamestown.org/program/georgian-special-servicespublicize-russias-attempts-to-subvert-country-from-within/.

- Menabde, Giorgi. 2018b. “Abkhazia and South Ossetia Reject Georgia's Peace Plan". Eurasia Daily Monitor, Vol. 15 issue 59, April 18, 2018. https://jamestown.org/program/abkhazia-and-south-ossetia-reject-georgiaspeace-plan/.

- Nikolsky, Andrei, and Nina Ilyina. 2016. “Обострение конфликта в Нагорном Карабахе застало Москву врасплох". Vedomosti, April 3, 2016. https:/ / www.vedomosti.ru/politics/articles/2016/04/04/636255-nagornomkarabahe.

- Rahimov, Rahim. 2018. "Azerbaijan, Iran Reach Breakthrough on Disputed Fields in the Caspian Sea". Eurasia Daily Monitor, Vol. 15 issue 52, April 5, 2018. https://jamestown.org/program/azerbaijan-iran-reach-breakthroughon-disputed-fields-in-the-caspian-sea/.

- $\quad$ RIA Novosti. 2016. “Медведев рассказал о возможном факторе сдерживания в Карабахе”. Accessed May 11, 2018. https:/ / ria.ru/world/20160409/1406122604.html.

- $\quad$ Rukhadze, Vasili. 2018. "Georgian Government Insists on Direct Talk With Moscow-Backed Separatists". Eurasia Daily Monitor, Vol. 15 issue 45, March 26, 2018. https://jamestown.org/program/georgian-government-insists-directtalk-moscow-backed-separatists/.

- $\quad$ Scrinic, Andrei. 2014. “The Eastern Partnership as Part of the EU Foreign Policy: A Review of Theoretical Approaches". In EURINT 2014. European Union in Times of Crisis. Perspectives and Solutions, edited by Gabriela Carmen Pascariu, Ramona Țigănașu and Cristian Încalțărău, 219-30. Iași: Alexandru Ioan Cuza University.

- Shahbazov, Fuad. 2018. "Baku Pushes New Azerbaijan-Iran-TurkeyGeorgia Grouping to Enhance Intra-Regional Cooperation". Eurasia Daily Monitor, Vol. 15 issue 46, March 27, 2018. https:/ /jamestown.org/program/baku-pushes-new-azerbaijan-iran-turkeygeorgia-grouping-enhance-intra-regional-cooperation/. 
- $\quad$ Shiriyev, Zaur. 2016. “Azerbaijan's War of Attrition: A New Strategy to Resolve the Karabakh Conflict?" Eurasia Daily Monitor, Vol. 13 issue 67, April 6, 2016. https://jamestown.org/program/azerbaijans-war-of-attrition-a-newstrategy-to-resolve-the-karabakh-conflict/.

- $\quad$ Shiriyev, Zaur, and Celia Davies. 2013. “The Turkey-Armenia-Azerbaijan Triangle: The Unexpected Outcomes of the Zurich Protocols". Perceptions 18(1): 185-206.

- $\quad$ SIPRI Military Expenditure Database. 2018. “Data for all countries from 1988-2017 in constant (2016) USD (pdf)". Accessed May 11, 2018. https://www.sipri.org/sites/default/files/1_Data \%20for\%20all\%20countries \%2 Ofrom \% 201988\%E2\%80\% 932017\%20in\%20constant \%20\%282016\%29\%20USD.pdf.

- Statistical Yearbook of Armenia. 2017. Yerevan: National Statistical Service of the Republic of Armenia.

- Strategic Policy Institute. 2017. South Caucasus Security Forum concluding report. 
EUROPOLITY, vol. 12, no. 1, 2018 